(C) Copyright 2020: Editum. Servicio de Publicaciones de la Universidad de Murcia. Murcia (Spain) ISSN print edition: 0212-9728. ISSN online edition (http://revistas.um.es/analesps): 1695-2294. Online edition License Creative Commons 4.0: BY-SA

\title{
Internet Addiction and Social Self-Efficacy: The Mediator Role of Loneliness
}

\author{
Fuad Bakioğlu
}

Karamanoğlu Mehmetbey University, Karaman (Turkey)

\begin{abstract}
Título: Adicción a internet y autoeficacia social: el papel mediador de la soledad.

Resumen: El propósito de este estudio fue examinar si la soledad es un mediador entre la adicción a internet y la autoeficacia social. Los participantes fueron 325 estudiantes universitarios (mujeres: 57.8\%; hombres: $42.2 \%)$. La edad de los participantes osciló entre 17 y 30 años $(M=20.54$ $D T=1.99)$. Los datos del estudio se obtuvieron mediante el Formulario Corto de Adicción a Internet de Young, la Escala de Eficacia Social y Expectativas de Resultados Sociales y la Escala de Soledad de UCLA. Los datos se analizaron utilizando el método de modelado de ecuaciones estructurales y bootstrapping. El modelo de ecuaciones estructurales mostró que había un efecto indirecto sobre la autoeficacia social, mediado por la soledad. Los resultados del procedimiento de arranque indicaron que el efecto indirecto de la soledad fue significativo. Se discutieron las posibles explicaciones, la implicación de la investigación, las limitaciones y las direcciones futuras.
\end{abstract}

Palabras clave: Autoeficacia social; Adicción a Internet; Soledad; Estudiantes universitarios; Turquía.

\section{Introduction}

The Internet is an important part of the daily life of every age group around the world. Individuals use the internet as a means of shopping, using social networks, entertainment, banking, communicating with people in remote countries and accessing all kinds of information. The fact that all these can be practiced quickly makes the internet an indispensable part of life. Gaining a wider popularity as well as easing the life, internet is used by $56.8 \%$ of world population and $68.4 \%$ of Turkish population (Internet Users, 2019). According to Turkish Statistical Institute (2018), the ratio of internet users in Turkey is $72.9 \%$ in the age range between 16 and 74 . This ratio shows that approximately three out of four people in Turkey are internet users. With the rapid advancement of technology, areas of internet access have increased. Internet access is available from notebooks, tablets and mobile phones. The fact that the internet is easily accessible increases the prevalence of its use. The widespread use of the Internet has positive as well as negative consequences.

The possible negative consequence of internet use is internet addiction (IA). Some concepts such as problematic internet users (Laconi et al. 2019; Vadher et al. 2019), internet dependents (Lin \& Tsai, 2002), impulsive-compulsive internet usage disorder (Dell'Osso et al. 2008) or patholocigal internet users (Davis 2001) are used for IA. IA is defined as the inability to prevent the excessive use of the Internet,

* Correspondence address [Dirección para correspondencia]: Fuad Bakioğlu, Ph.D., Karamanoğlu Mehmetbey University, Faculty of Education, Department of Psychological Counseling and Guidance, 70000, Karaman (Turkey). E-mail: fuadbakioglu@kmu.edu.tr

(Article received: 27-08-2019; revised: 21-12-2019; accepted: 06-02-2020)
Abstract: The purpose of this study was to examine whether loneliness is a mediator between internet addiction and social self-efficacy among undergraduates. The participants involved 325 undergraduates (female: $57.8 \%$; male, $42.2 \%$ ). The age of participants ranged between 17 and 30 years $(M=20.54, S D=1.99)$. The study data was gathered using the Young's Internet Addiction Test-Short Form, the Social Efficacy and Social Outcome Expectation Scale and the UCLA Loneliness Scale. The data were analyzed using structural equation modeling and bootstrapping method. Structural equation modeling showed that internet addiction had an indirect effect on social self-efficacy, mediated by loneliness. The results of bootstrapping procedure indicated that the indirect effect of loneliness on the relationship between internet addiction and social selfefficacy was significant. The possibility explanations, the research implication, limitations, and future directions were discussed.

Keywords: Social self-efficacy; Internet addiction; Loneliness; Undergraduates; Turkey. considering the time wasted without being connected to the Internet, excessive nervousness and aggression when deprived, and the deterioration of one's professional, social, and family life (Kraut et al. 1998; Öztürk et al. 2007; Young 2004). IA develops towards content and opportunities provided by the internet rather than the Internet itself.

In the last decade, a great number of research has been carried out on IA. In these research, the relationship between IA and social and personal variables was revealed. For example, IA decreased life satisfaction (Blachnio et al. 2018; Bozoğlan, Demirer \& Şahin, 2013) and wellbeing (Cheung et al. 2018) while it increased social isolation (Shaw \& Black, 2008), social phobia (Elavarasan et al. 2018), anxiety (Shaikhamadi et al. 2018), and depression (Günay et al. 2018). In addition, IA has been found to be related to fivefactor personality traits (Kayış et al. 2016). Revealing the variables with which IA is related is effective in determining the possible negative consequences. In this study, the social selfefficacy and loneliness were focused in relation with IA.

\section{Background}

\section{Social Self-Efficacy}

Social self-efficacy is based on the theory of self-efficacy discussed by Albert Bandura $(1977,1997)$ in Social Cognitive Learning Theory. Self-efficacy expresses the belief that the performance of the individual who will perform in the future will be successful (Bandura 1994). Social self-efficacy is an individual's confidence and ability to initiate and maintain social relationships (Bakioğlu \& Türküm, 2017; Wright, Wright \& Jenkins-Guarnieri, 2013). Moreover, social self- 
efficacy is one's belief in his/her skills in establishing and developing new friendships (Smith \& Betz, 2000).

In the body of research, it was found that social selfefficacy was negatively associated with depression (Anderson \& Betz, 2001; Ahmad, Yasien \& Ahmad, 2014; Hermann \& Betz, 2006), social anxiety (Fan et al. 2010; Smith \& Betz, 2000) and shyness (Anderson \& Betz, 2001; Hermann and Betz, 2004) while it was positively associated with life satisfaction (Bakioğlu \& Türküm, 2017; Wright \& Perrone, 2010), self-respect (Hermann \& Betz, 2006; Smith \& Betz, 2000) and problem solving skills (Di Giunta et al. 2010; Erözkan 2013). Social self-efficacy is also associated with internet addiction. (Kaur, 2018; Mohammadi \& Torabi, 2018). The results of the research indicate that internet addiction negatively affects social self-efficacy. As internet addiction increases, the level of social self-efficacy decreases. Failure to control the time spent on the Internet may cause the individual to move away from the real world and avoid initiating and maintaining social relationships. As a matter of fact, the results of research indicate that internet addiction provides an environment for decreasing social self-efficacy and loneliness of the individual.

\section{Loneliness}

When individuals are involved in inadequate and unsatisfactory social relations and experiences, they isolate themselves from the environment and society and are left alone. As a source for unhappiness, loneliness is seen as an inconsistency between the individual's desired and attained social relationships (Perlman \& Peplau, 1981) and a state of weakness (Kaymaz, Eroğlu \& Sayılar, 2014; Özçelik \& Barsade, 2011).

Loneliness is approached as emotional and social loneliness (Weiss, 1973). Emotional loneliness is a subjective assessment of an individual's inability to make a sincere and reliable friend. Social loneliness means that the individual has fewer friends and social relationships than he thinks and desires (Eraslan-Çapan \& Sarıçalı; 2016; Şişman \& Turan, 2004).

As individuals get lonely, they have difficulties in establishing social relationships and maintaining existing relationships. Thus, individuals can choose to focus on the weaknesses rather than focusing on their own and others' strengths (Copel 1988). Loneliness leads to alienation, reduced social ties, increased desire to be alone, isolation from others and increased feelings of inadequacy (Brelim 1985). As a result, loneliness results in an individual pushing himself/herself out of real life and assuming every challenge in life alone.
Although loneliness is associated with many personal variables, it is positively associated with IA (Ceyhan \& Ceyhan, 2008; Çağır 2010; Eldeleklioğlu \& Vural, 2013; Huan, Ang \& Chye, 2014; Ümmet \& Ekşi, 2016; Whang, Lee \& Chang, 2003) while it is negatively associated with social self-efficacy (Bakioğlu \& Türküm, 2017; Hermann \& Betz, 2006). In other words, as internet addiction increases, individuals become lonelier. Moreover, social self-efficacy decreases as loneliness increases.

\section{The Present Study}

Since undergraduates are mainly far from their home, they turn onto interpersonal relationships and are not able to make use of their spare time, leading them to become more addicted to internet (Kandell 1998). Therefore, it is considered important to examine the mediating role of loneliness between internet addiction and social self-efficacy of undergraduates in this study.

The results of studies indicate that IA increases loneliness (Bozoglan, Demirer \& Sahin, 2013; Chen, 2012; Esen, Aktas \& Tuncer, 2013; Morahan Martın \& Schumacher, 2003; Pontes, Griffiths \& Patrao, 2014). In other words, as internet usage increases, individuals become lonely. Therefore, IA also causes a decrease in social self-efficacy (Kaur, 2018; Mohammadi \& Torabi, 2018).

Loneliness was an important personal factor in the reduction of social self-efficacy. The increase in internet addiction of university students, especially in the period of young adulthood, caused their loneliness (Kaur, 2018; Mohammadi \& Torabi, 2018). The social self-efficacy of young adults who became isolated was decreasing. Therefore, it was considered important to examine the mediating role of loneliness between internet addiction and social self-efficacy. Examining the effects of internet addiction of university students in Turkey caused by loneliness, social self-efficacy, social selfefficacy and means to increase the role by demonstrating effective measures will be taken.

Despite all these findings, when the available literature was examined, no research examining the relationship among internet addiction, loneliness, and social competence was found. The hypothesis of this research argues that IA is positively associated with loneliness while it is negatively associated with social self-efficacy. Moreover, it was also aimed at investigating the mediating role of loneliness in the relationship between internet addiction and social self-efficacy. The hypothesized model regarding this purpose can be seen in Figure 1. 


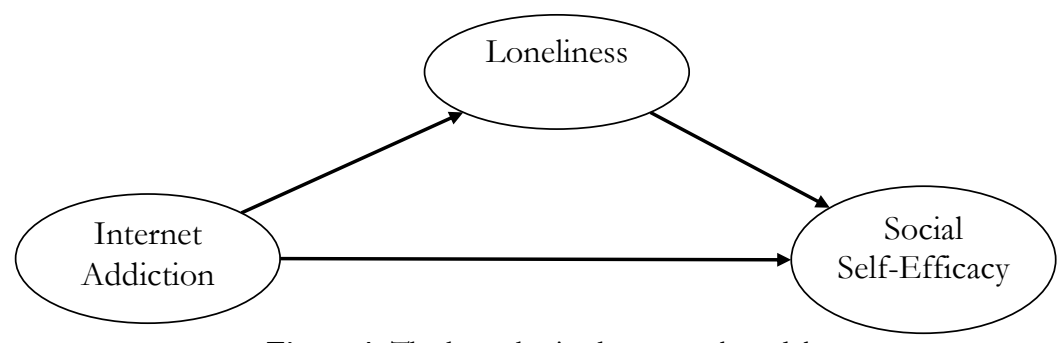

Figure 1. The hypothesized structural model.

\section{Method}

\section{Participants}

In this study, convenience sampling method was used. The research data were collected from undergraduate student at a state university located in the Black Sea region of Turkey. Participants consisted of 325 voluntary undergraduates in Turkey. The data were collected between November and December 2018. The ages of the participants ranged from 17 to 30 years (Mean Age $=20.54$, Standard Deviation $=1.99)$. Of these, $188(57.8 \%)$ were female and $137(42,2 \%)$ were male.

\section{Measures}

Young's Internet Addiction Test-Short Form: Internet addiction was measured with the Young's Internet Addiction Test-Short Form (YIAT-SF) developed by Young (1998). The short form of the YIAT-SF was formed by Pawlikowski, Altstötter-Gleich and Brand (2013). The YIAT-SF is a self-report questionnaire with 12 items. Items are rated on a 5 -point Likert scale from 1 (rarely) to 5 (always). Items include statements such as "How often do you find that you stay on-line longer than you intended?". The total score of the Turkish-YIAT-SF was the sum of the 12 items, with the range from 12 to 60 with higher scores indicating higher level of internet addiction. YIAT-SF was translated into Turkish by Kutlu, Savc1, Demir and Aysan (2016). YIAT-SF have good construct validity $\left(\chi^{2} / \mathrm{df}=2.78\right.$, RMSEA $=.07, \mathrm{GFI}=$ $.93, \mathrm{AGFI}=.90, \mathrm{CFI}=.95, \mathrm{IFI}=.91$ and $\mathrm{RMR}=.07)$ and internal reliability (Cronbach's $\alpha=.91$ ) and test-retest reliability coefficients $(\alpha=.93)$. In this study, the YIAT also exhibited excellent reliability (Cronbach's $\alpha=.86$ ).

Social Efficacy and Social Outcome Expectation Scale: Social self-efficacy was measured with the Social Efficacy and Social Outcome Expectation Scale (SEOES) developed by Wright, Wright and Jenkins-Guarnieri (2013). The SEOES is a self-report questionnaire with 19 items and two components (social efficacy and social outcome expectation). Items are rated on 5-point Likert scale from 1 (strongly disagree) to 5 (strongly agree). Examples of items are "I am confident in my skills to be in social relationships" for social efficacy, and "Talking with others will increase my social relationships" for social outcome expectation. The total score of the SEOES is the sum of the 19 items, with the range from
19 to 95 with higher scores indicating higher levels of social efficacy. SEOES was translated into Turkish by Bakioğlu and Türküm (2017). SEOES have good construct validity $\left(\chi^{2} / \mathrm{df}\right.$ $=2.76$, RMSEA $=.07, \mathrm{GFI}=.89, \mathrm{AGFI}=.86, \mathrm{CFI}=.98$, $\mathrm{NFI}=.96$ and $\mathrm{SRMR}=.02$ ) and internal reliability (Cronbach's $\alpha=.92$ and .81 for SES and OES respectively). In this study, the SEOES also exhibited excellent reliability (Cronbach's $\alpha=.93$ and .80 for SES and OES, respectively).

UCLA Loneliness Scale: Loneliness was measured with the UCLA Loneliness Scale (UCLA-8) developed by Russel, Peplau and Ferguson (1978). The short form of the UCLA-8 was formed by Hays and Dimatteo (1987). The UCLA-8 is a self-report questionnaire with 8 items. Items are rated on 4point Likert scale from 1 (never) to 4 (always). Items include statements such as "I don't have a friend". The total score of the UCLA- 8 is the sum of the 8 items ranging from 8 to 32 with higher scores indicating a higher loneliness level. UCLA-8 was translated into Turkish by Doğan, Çötok and Tekin (2011). UCLA-8 have good construct validity $\left(\chi^{2} / \mathrm{df}=\right.$ 1.83, RMSEA $=.05, \mathrm{GFI}=.99, \mathrm{AGFI}=.96, \mathrm{CFI}=.99, \mathrm{IFI}$ $=.99, \mathrm{NFI}=.99$ and SRMR $=.03)$ and internal reliability coefficients (Cronbach's $\alpha=$.83). In this study, the UCLA-8 also exhibited good reliability (Cronbach's $\alpha=.77$ ).

\section{Procedure}

The data of the research were collected in a classroom setting from the volunteers through a pen-and-paper form. The informed consent form was presented to participants and they were asked to tick the box indicating that they were taking part in the study voluntarily. A total of 325 undergraduates participated in the research while five cases were excluded since nearly half of them had missing values. Before collecting the data, the participants were informed about the purpose and significance of the research. It was emphasized that no personal information was asked from the participants. It took about 20 minutes for participants to fill in the survey.

\section{Data Analysis}

The analyses were conducted in two steps. Firstly, the measurement model and discriminative validity was tested. Secondly, the structural equation model was tested. Maximum likelihood estimation technique was used in structural equation modelling. Moreover, parceling technique was used 
to reduce the number of observed variables and improve the reliability and normality (Nasser-Abu Alhija \& Wisenbaker, 2006). Two parcels were formed for each IA and loneliness (Little et al. 2002). Various fit indices (e.g. $\chi^{2} / \mathrm{df}<5$, CFI, TLI, GFI, IFI >.90, SRMR and RMSEA <.08, Hu \& Bentler, 1999; MacCallum et al. 1996; Tabachnick \& Fidell, 2013) were used to evaluate the model fit. The values of kurtosis and skew-ness were calculated in order to check normality of the data. Because the values of skewness and kurtosis range between +1 and -1 (Table 2) the data has been considered to have a normal distribution (Tabachnick \& Fidell, 2013).

Bootstrapping analysis was conducted to determine whether loneliness played a mediator role in the relationship between IA and social self-efficacy (Preacher \& Hayes, 2008). Bootstrapping analysis tests the significance of direct and indirect effects in bigger samples (MacKinnon, Lockwood, \& Williams, 2004). The value range obtained from this analysis should not involve zero (Hayes, 2013). The analyses were conducted using IBM SPSS ${ }^{\circledR}$ Statistics 21.00 and IBM
SPSS $^{\circledR}$ Amos 23.00 software. Moreover, MS Excel was used to estimate internal consistency and discriminative validity.

\section{Results}

\section{Measurement Model and CFA}

In this research, the first step involved the test of measurement model. In the measurement model, there was three latent variables (IA, social self-efficacy, loneliness) and six observed variables. It was observed that all path coefficients of the measurement model were significant. The examination of goodness of fit indices of the measurement model $\left(\chi^{2}(6\right.$, $\mathrm{N}=325)=4.90, \mathrm{p}<.001 ; \chi^{2} / \mathrm{df}=.56 ; \mathrm{CFI}=1.00 ; \mathrm{TLI}=1.00 ;$ $\mathrm{GFI}=.99 ; \mathrm{SRMR}=.014$; RMSEA $=.01$; C.I. $[.47, .96])$ revealed that the model had a good fit. The summary of the CFA is presented in Table 1 .

Table 1. Summary of the CFA.

\begin{tabular}{|c|c|c|c|c|c|c|c|}
\hline Variables & Factor Mean & Factor $S D$ & Factor alpha & Composite reliability & AVE & Loading & Error \\
\hline \multicolumn{8}{|l|}{ Internet Addiction } \\
\hline İnadPar1 & 27.36 & 8.08 & .86 & .77 & .68 & .83 & .31 \\
\hline İnadPar2 & & & & & & .75 & .44 \\
\hline \multicolumn{8}{|l|}{ Social Self-Efficacy } \\
\hline Social Efficacy & 77.03 & 10.92 & .93 & .68 & .53 & .78 & .40 \\
\hline Social Outcome & & & & & & .66 & .57 \\
\hline \multicolumn{8}{|l|}{ Loneliness } \\
\hline LonePar1 & 14.73 & 4.77 & .77 & .68 & .52 & .70 & .51 \\
\hline LonePar2 & & & & & & .74 & .45 \\
\hline
\end{tabular}

As can be seen in Table 1, it was found that internal consistency indices were above .70 (Huck, 2012; Nunnally, 1978) while the factor loadings were above .32 (Worthington and Whittaker, 2006). Moreover, the measurement model explained $55.32 \%$ of the total variance. The rule of thumb indicates that the measurement model is expected to explain at least $50 \%$ of the total variance (Henson \& Roberts, 2006). Additionally, convergent and discriminant validity were examined (Fornell \& Larcker, 1981). It was observed that composite reliability coefficients were above .60 (Nunnally, 1978) and AVE (average variance extracted) scores were above .50. The factor loads of all variables ranged from .70 to .83 . All these results showed that the observed variables represent latent variables.

\section{Preliminary Analyses}

In this research, undergraduates' levels of IA, social selfefficacy, and loneliness were tested through structural equation modelling. After the measurement model was tested in the first step, descriptive statistics were estimated prior to the structural equation modelling analysis. The findings of descriptive statistics and correlation analysis are presented in Table 2.
Table 2. Correlations among the variables of interest.

\begin{tabular}{lllllll}
\hline Variable & 1 & 2 & 3 & 4 & 5 & 6 \\
\hline 1. InadPar1 & - & & & & & \\
2. InadPar2 & $.77^{* *}$ & - & & & & \\
3. SES & $-.52^{* *}$ & $-.41^{* *}$ & - & & & \\
4. SOS & $-.43^{* *}$ & $-.34^{* *}$ & $.62^{* *}$ & - & & \\
5.LonePar1 & $.44^{* *}$ & $.38^{* *}$ & $-.43^{* *}$ & $-.29^{* *}$ & - & \\
6.LonePar2 & $.49^{* *}$ & $.39^{* *}$ & $-.48^{* *}$ & $-.32^{* *}$ & $.61^{* *}$ & - \\
$\quad$ Mean & 13.92 & 13.44 & 51.42 & 25.61 & 7.31 & 7.42 \\
$\quad$ SD & 4.30 & 4.27 & 8.65 & 3.21 & 2.69 & 2.64 \\
Skewness & -.15 & .48 & -.35 & -.40 & .46 & .57 \\
Kurtosis & -.31 & -.45 & .26 & -.09 & -.67 & -.14
\end{tabular}

Note. ${ }^{* *} p<.01$, InadPar internet addiction parcels, SES social efficacy scale, SOS social outcome expectation scale, LonePar loneliness parcels, $S D$ standard deviation.

Table 2 shows that IA parcels were negatively correlated with social efficacy and social expectation parcels $(r=-.52 \leq r$ $\leq-.34, p<.01)$ while they were positively correlated with loneliness parcels positively $(\mathrm{r}=.38 \leq \mathrm{r} \leq .49, \mathrm{p}<.01)$. Moreover, loneliness parcels were negatively correlated with social efficacy and social expectation parcels $(r=-.48 \leq r \leq-.29$, $p<.01)$. 


\section{Main Analyses}

Secondly, structural equation model was tested. In this model, the possible mediator role of loneliness in the relationship between IA and social self-efficacy was tested. The results of the structural equation modelling can be seen in Figure 2.
All path coefficients in the model were significant. Internet addiction predicted social self-efficacy negatively $(\beta=$ $.33, p<.01)$ and loneliness positively $(\beta=.61, p<.01)$. In addition, loneliness predicted social self-efficacy negatively $(\beta=$ $.43, p<.01)$. Moreover, the effect coefficient of internet addiction predicting social self-efficacy through the mediation of loneliness was estimated to be -.26 .

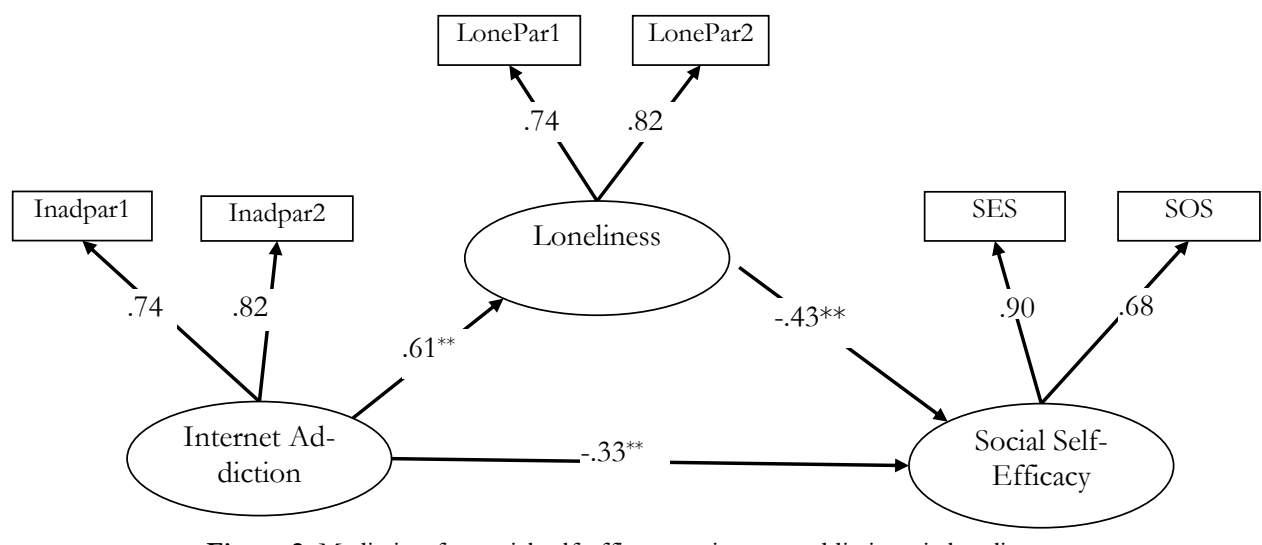

Figure 2. Mediation for social self-efficacy on internet addiction via loneliness.

The examination of fit indices regarding the structural model showed that all of them indicated perfect fit $\left(\chi^{2}(6, \mathrm{~N}=\right.$ ${ }_{325)}=4.90, p<.001 ; \chi^{2} / \mathrm{df}=.56 ; \mathrm{GFI}=.99 ; \mathrm{CFI}=1.00 ; \mathrm{NFI}$ $=.99 ; \mathrm{TLI}=1.00 ; \mathrm{SRMR}=.014 ; \mathrm{RMSEA}=.001)$. Based on these findings, it can be expressed that the structural model was confirmed.

\section{Bootstrapping analysis}

The mediator role of loneliness in the relationship between undergraduates' IA and social self-efficacy was tested through bootstrapping procedure. In this procedure, 10,000 resampling and 95\% confidence interval (CIs) were used. The coefficients and confidence intervals regarding the direct and indirect effects obtained from the bootstrapping procedure can be seen in Table 3 .

Table 3. Parameters and $95 \%$ CIs for the paths of the mediated model.

\begin{tabular}{lccc}
\hline & & \multicolumn{2}{c}{$95 \%$ C. I. } \\
\cline { 3 - 4 } Model paths & Coefficient & Lower & Upper \\
\hline Direct effect & & & -.18 \\
$\quad$ Internet addiction $\rightarrow$ Social self-efficacy & -.33 & -.49 & .70 \\
$\quad$ Internet addiction $\rightarrow$ loneliness & .61 & .50 & -.25 \\
$\quad$ Loneliness $\rightarrow$ Social self-efficacy & -.43 & -.59 & -.16 \\
$\quad$ Indirect effect & -.31 & -.38 & \\
$\quad$ Internet addiction $\rightarrow$ Loneliness $\rightarrow$ Social self-efficacy & &
\end{tabular}

Table 3 shows that direct effects were significant. Moreover, the model proposing the mediator role of loneliness in the relationship between IA and social self-efficacy was confirmed [effect $=-.31 ; \mathrm{CI}=(-.38,-.16)]$. Therefore, it can be stated that the university students' internet addiction had an effect on their social self-efficacy through the mediation of loneliness according to the bootstrapping results.

\section{Discussion}

The aim of this study was to investigate the relationships between internet addiction, social self-efficacy, and loneliness. The results showed that loneliness had a mediator role in the relationship between IA and social self-efficacy. All of the goodness of fit indices of the structural equation model were at acceptable level (Hu \& Bentler, 1999).

Discussing each of the results is important to understand the relationships among the variables. Firstly, as hypothesized, internet addiction predicted social self-efficacy negatively. This finding is consistent with the results of other studies (Kaur, 2018; Mohammadi \& Torabi, 2018). As a matter of fact, the time spent on the internet for internet addicts cannot be controlled. As the individual spends time on the internet, it becomes more difficult for him to establish oneto-one social relationships. Therefore, as the level of internet addiction increases, social self-efficacy decreases.

Secondly, as hypothesized, internet addiction predicted loneliness positively. This finding is supported by the litera- 
ture (Bozoglan, Demirer \& Sahin, 2013; Chen, 2012; Esen, Aktas \& Tuncer, 2013; Morahan Martın \& Schumacher, 2003). As individuals spend more time on the internet, they isolate themselves from others and experience the feeling of being alone. As a matter of fact, the lack of control of the time spent on the internet results in the deepening of loneliness.

As the third, loneliness predicted social self-efficacy negatively. Other studies revealed similar results (Bakioğlu \& Türküm, 2017; Hermann \& Betz, 2006; İskender \& Akın, 2010). As loneliness level increases, social self-efficacy decreases. Moreover, the individual who consciously chooses loneliness or who is forced to loneliness gradually decreases his/her belief in his/her ability to initiate new social relationships (Fees, Martin \& Poon, 1999; Copel 1988). Thus, the individual focuses on his own weaknesses and avoids socializing. All of these indicate that loneliness reduces social selfefficacy.

Finally, in this study, it was found that loneliness had a mediator role in the relationship between IA and social selfefficacy. As the time spent on the internet increases, the individual also breaks away from social life. As a matter of fact, the individual spends most of his time on the internet. As the individual spends time on the internet, their social relations become weaker and they become lonely (İskender 2018). As a result, the lonely individual gradually decreases his/her belief in social self-efficacy. Individuals whose experience in initiating and maintaining social relationships are diminishing and whose previous social relationships are damaged avoid establishing new social relationships. As a matter of fact, university period involves the ages in which individuals acquire new relationship experiences. However, when a social relationship cannot be established at this age, the individual cannot fulfill his/her basic life tasks.

\section{Conclusion}

In this study, the mediator role of loneliness in the relationship between internet addiction and social self-efficacy was determined. Excessive and uncontrolled use of the internet by especially undergraduates causes them to become lonely and decrease their competence in initiating and maintaining

\section{References}

Ahmad, Z. R., Yasien, S., \& Ahmad, R. (2014). Relationship between perceived social self-efficacy and depression in adolescents. Iranian Journal of Psychiatry and Behavioral sciences, 8(3), 65.

Anderson, S. L., \& Betz, N. E. (2001). Sources of social self-efficacy expectations: Their measurement and relation to career development. Journal of Vocational Behavior, 58(1), 98-117. doi:10.1006/jvbe.2000.1753

Bakioglu, F., \& Turkum, A. S. (2017). Psychometric Properties of Adaptation of the Social Efficacy and Outcome Expectations Scale to Turkish. European Journal of Educational Research, 6(2), 213-223. doi:10.12973/eu-jer.6.2.213

Bandura, A. (1977). Self-efficacy: Toward a unifying theory of behavioral change. Psychological Review, 84 (2), 191-215. social relations. This research was designed and carried out as the structural equation model. Paving the way for the socialization of undergraduates and supporting them will enable them to improve themselves professionally and personally and to realize themselves. Given the rate of internet use in Turkey, the results of this research is to contribute to the literature reveal potential negative consequences in terms of internet addiction.

\section{Limitations}

Although this study revealed the mediator role of loneliness in the relationship between Turkish undergraduates' internet addiction and social self-efficacy using structural equation modelling, it has some limitations as well. First of all, the personal characteristics and sample size of the undergraduates did not represent all Turkish undergraduates. The larger the sample used in further research and Turkey's inclusion in the research of university students from different regions may increase the generalizability of the study.

\section{Implications}

Future studies are recommended to include undergraduates from different regions of Turkey and to increase the sample size to ensure the generalizability of the research. Secondly, self-report scales were used in this study. Qualitative data collection methods can also be used in the data collection process. Finally, the study was a cross-sectional research. Cross-sectional data are not used to reveal causal implications. Although the structural equation models examine the effects, experimental studies can reach true causal results.

In this study, mediating role of loneliness between internet addiction and social self-efficacy of university students was examined. Based on the results of the research, psychological counseling services can be extended and disseminated within universities in order to increase the social competence of university students. Psychoeducational studies, group psychological counseling and information seminars can be conducted in order to increase the social self-efficacy of the university students by increasing their skills in starting and maintaining social relationships.

Bandura, A. (1994). Self-efficacy. V.S. Ramachaudran (Editor), Encyclopedia of human behavior içinde (Vol. 4, s. 71-81). New York: Academic Press.

Bandura, A. (1997). Self-efficacy: The exercise of control. New York: W. H. Freemen Company.

Błachnio, A., Przepiorka, A., Benvenuti, M., Mazzoni, E., \& Seidman, G. (2018). Relations Between Facebook Intrusion, Internet Addiction, Life Satisfaction, and Self-Esteem: A Study in Italy and the USA. Inter national Journal of Mental Health and Addiction, 1-13. doi:0.1007/s11469018-0038-y

Bozoğlan, B., Demirer, V., \& Şahin, I. (2013). Loneliness, self-esteem, and life satisfaction as predictors of Internet addiction: A cross-sectional 
study among Turkish university students. Scandinavian Journal of Psychology, 54(4), 313-319. doi:10.1111/sjop.12049

Brelim, S. (1985). "Intimate Relationships". Random House, NewYork.

Ceyhan, A., \& Ceyhan, E. (2008). Loneliness, depression, and computer self-efficacy as predictors of problematic internet use. CyberPsychology \& Behavior, 11(6), 699-701. doi:10.1089/cpb.2007.0255

Chen, S.-K. (2012). Internet use and psychological well-being among college students: A latent profile approach. Computers in Human Behavior, 28(6), 2219- 2226. doi:10.1016/j.chb.2012.06.029

Cheung, J. C. S., Chan, K. H. W., Lui, Y. W., Tsui, M. S., \& Chan, C. (2018). Psychological well-being and adolescents' internet addiction: a school-based cross-sectional study in Hong Kong. Child and Adolescent Social Work Journal, 35(5), 477-487. doi:0.1007/s10560-018-0543-7

Copel, L.C. (1988). Loneliness: A conceptual model. Journal of Psychosocial Nursing and Mental Health Nursing, 26(1),14-19.

Çağır, G. (2010). The relation between the well-being states perceiving thanks to problemeatic internet usage of high school and university students and their loniless level. Unpublished Master Thesis, Balıkesir University, Institute of Social Sciences.

Davis, R. A. (2001). A cognitive-behavioral model of pathological Internet use. Computers in buman behavior, 17(2), 187-195. doi:10.1016/S07475632(00)00041-8

Dell'Osso, B., Hadley, S., Allen, A., Baker, B., Chaplin, W. F., \& Hollander, E. (2008). Escitalopram in the treatment of impulsive-compulsive internet usage disorder: an open-label trial followed by a double-blind discontinuation phase. The Journal of clinical psychiatry, 69(3), 452-456. doi:10.4088/JCP.v69n0316

Di Giunta, L., Eisenberg, N., Kupfer, A., Steca, P., Tramontano, C., \& Caprara, G. V. (2010). Assessing perceived empathic and social selfefficacy across countries. European Journal of psychological assessment, 26, 77-86. doi:10.1027/1015-5759/a000012

Doğan, T., Çötok, N. A., \& Tekin, E. G. (2011). Reliability and validity of the Turkish Version of the UCLA Loneliness Scale (ULS-8) among university students. Procedia-Social and Behavioral Sciences, 15, 2058-2062. doi:10.1016/j.sbspro.2011.04.053

Elavarasan, K., Dhandapani, T., Norman, P., Vidya, D. C., \& Mani, G. (2018). The association between internet addiction, social phobia and depression in medical college students. International Journal of Community Medicine and Public Health, 5(10), 4351-4356. doi:10.18203/23946040.ijcmph20183973

Eldeleklioğlu, J.., \& Vural, M. (2013). Predictive effects of academic achievement, internet use duration, loneliness and shyness on internet addiction. Hacettepe University Journal of Education, 28(28-1), 141-152.

Eraslan Çapan, B., \& Sarıçal, M. (2016). "The role of social and emotional loneliness in problematic Facebook use", Inönü University Journal of the Faculty of Education, 17(3),53-66. doi:10.17679/iuefd.17306122

Erözkan, A. (2013). The effect of communication skills and interpersonal problem solving skills on social self-efficacy. Educational Sciences: Theory and Practice, 13(2), 739-745.

Esen, B. K., Aktas, E., \& Tuncer, I. (2013). An Analysis of University Students' Internet Use in Relation to Loneliness and Social Self-efficacy. Procedia-Social and Behavioral Sciences, 84, 1504-1508. doi:10.1016/j.sbspro.2013.06.780

Fan, J., Meng, H., Gao, X., Lopez, F. J., \& Liu, C. (2010). Validation of a U.S. adult social self-efficacy inventory in Chinese populations. The Counseling Psychologist, 38(4), 473-496. doi: $10.1177 / 0011000009352514$

Fees, B. S., Martin, P., \& Poon, L. W. (1999). A model of loneliness in older adults. Journal of Gerontology, Psychological Sciences, 54B, 231-239. doi:10.1093/geronb/54B.4.P231

Fornell, C., \& Larcker, D. F. (1981). Structural equation models with unobservable variables and measurement error. Journal of Marketing Research, 18, 39-50. doi:10.1177/002224378101800313

Gunay, O., Ozturk, A., Arslantas, E. E., \& Sevinc, N. (2018). Internet addiction and depression levels in Erciyes University students. Düs̈̈nen Adam Journal of Psychiatry \& Neurological Sciences, 31(1), 79-88. doi:10.5350/DAJPN2018310108

Hays, R. D., \& DiMatteo, M. R. (1987). A short-form measure of loneliness. Journal of personality assessment, 51(1), 69-81.
Henson, R.K., \& Roberts, J.K., (2006). Use of exploratory factor analysis in published research. Educational and Psychological measurement, 66(3), 393 416. doi:10.1177/0013164405282485

Hermann, K. S., \& Betz, N. E. (2004). Path models of the relationships of instrumentality and expressiveness to social self-efficacy, shyness, and depressive symptoms. Sex Roles, 51, 55-66. doi:10.1023/B:SERS.0000032309.71973.14

Hermann, K. S., \& Betz, N. E. (2006). Path models of the relationships of instrumentality and expressiveness, social self-efficacy, and self-esteem to depressive symptoms in college students. Journal of Social and Clinical Psychology, 25, 1086-1106. doi:10.1521/jscp.2006.25.10.1086

Hu, L. T., \& Bentler, P. M. (1999). Cutoff criteria for fit indexes in covariance structure analysis: conventional criteria versus new alternatives. Structural Equation Modeling: A Multidisciplinary Journal, 6(1), 1-55. doi:10.1080/10705519909540118

Huan, V.S., Ang, R.P., Chye, S. (2014). Loneliness and shyness in adolescent problematic internet users: the role of social anxiety. Child \& Youth Care Forum, 43(5), 539-551. doi:10.1007/s10566-014-9252-3

Huck, S. W. (2012). Reading Statistics and Research, 6th ed. Pearson, Boston.

Internet Users. (2019). http://www.internetlivestats.com/internet-users

Iskender, M. (2018). Investigation of the effects of social self-confidence, social loneliness and family emotional loneliness variables on internet addiction. Malaysian Online Journal of Educational Technology, 6(3), 1-10. doi:10.17220/mojet.2018.03.001

İskender, M., Akin, A. (2010). Social self-efficacy, academic locus of control, and internet addiction. Computers \& Education, 54, 1101-1106. doi:10.1016/j.compedu.2009.10.014

Kandell, J. J. (1998). Internet addiction on campus: The vulnerability of college students. Cyberpsychology \& behavior, 1(1), 11-17. doi:10.1089/cpb.1998.1.11

Kaur, S. (2018). Gender differences and relationship between internet addiction and perceived social self-efficacy among adolescents. Indian Journal of Health \& Wellbeing, 9(1), 106-109.

Kayiş, A. R., Satici, S. A., Yilmaz, M. F., Şimşek, D., Ceyhan, E., \& Bakioğlu, F. (2016). Big five-personality trait and internet addiction: A meta-analytic review. Computers in Human Behavior, 63, 35-40. doi:10.1016/j.chb.2016.05.012

Kaymaz, K., Eroğlu, U., \& Sayılar, Y. (2014). "Effect of Loneliness at Work on the Employees' Intention to Leave". Industrial Relations and Human Resources Journal, 16(1),38-53. doi:10.4026/1303-2860.2014.0241.x

Kraut, R., Patterson, M., Lundmark, V., Kiesler, S., Mukopadhyay, T., \& Scherlis, W. (1998). Internet paradox: A social technology that reduces social involvement and psychological well-being? American Psychologist, 53(9), 1017-1031.

Kutlu, M., Savci, M., Demir, Y., \& Aysan, F. (2016). Turkish adaptation of Young's Internet Addiction Test-Short Form: a reliability and validity study on university students and adolescents. Anatolian Journal of Psychiatry, 17, 69-76. doi:10.5455/apd.190501

Laconi, S., Urbán, R., Kaliszewska-Czeremska, K., Kuss, D. J., Gnisci, A., Sergi, I., ... \& Ozcan, N. K. (2019). Psychometric evaluation of the nine-item Problematic Internet Use Questionnaire (PIUQ-9) in nine European samples of internet users. Frontiers in Psychiatry, 10, 136. doi:10.3389/fpsyt.2019.00136

Lin, S. S., \& Tsai, C. C. (2002). Sensation seeking and internet dependence of Taiwanese high school adolescents. Computers in buman behavior, 18(4), 411-426. doi:10.1016/S0747-5632(01)00056-5

Little, T.D., Cunningham, W.A., Shahar, G., \& Widaman, K.F. (2002). To parcel or not to parcel: Exploring the question, weighing the merits. Structural equation modeling, 9(2), 151-173. doi:10.1207/S15328007SEM0902_1

MacCallum, R.C., Browne, M.W., \& Sugawara, H.M. (1996). Power analysis \& determination of sample size for covariance structure modeling. Psychological Methods, 1(2), 130-149. doi:10.1037/1082989X.1.2.130

MacKinnon, D. P., Lockwood, C. M., \& Williams, J. (2004). Confidence limits for the indirect effect: Distribution of the product and resampling methods. Multivariate behavioral research, 39(1), 99-128. doi:10.1207/s15327906mbr3901_4

Mohammadi, K., \& Torabi, B. (2018). Study of two main aspects of development (moral development and social self-efficacy) as predictors of 
internet addiction and student academic failure. Iranian Journal of Positive Psychology, 4(2), 39-45.

Morahan Martin, J., \& Schumacher, P. (2003). Loneliness and social uses of the Internet. Computers and Human Behavior, 19(6), 659-671. doi:10.1016/S0747-5632(03)00040-2

Nasser-Abu Alhija, F., \& Wisenbaker, J. (2006). A Monte Carlo study investigating the impact of item parceling strategies on parameter estimates and their standard errors in CFA. Structural Equation Modeling, 13(2), 204-228. doi:10.1207/s15328007sem1302_3

Nunnally, J.C. (1978). Psychometric Theory, 2nd ed. McGraw-Hill, New York.

Özcelik, H., \& Barsade, S. (2011). Work Loneliness and Employee Performance. Academy of Management Annual Meeting Proceedings, 16.doi:10.5465/ambpp.2011.65869714

Öztürk, Ö., Odabaşıŏlu, G., Eraslan, D., Genç, Y., \& Kalyoncu, Ö. A. (2007). Internet addiction: clinical aspects and treatment strategies. Journal of Dependence, 8(1), 36-41.

Pawlikowski, M., Altstötter-Gleich, C., \& Brand, M. (2013). Validation and psychometric properties of a short version of Young's Internet Addiction Test. Computer and Human Behavior, 29(3), 1212-1223. doi:10.1016/j.chb.2012.10.014

Perlman, D., \& Peplau, L. A. (1981). "Toward a Social Psychology of Loneliness". (Eds.). R. Gilmour, \& S. Duck, Personal Relationships: 3. Relationships in Disorder, 31-56. London: Academic Press.

Pontes, H. M., Griffiths, M. D., \& Patrão, I. M. (2014). Internet addiction and loneliness among children and adolescents in the education setting: an empirical pilot study. Aloma: Revista de Psicologia, Ciències de l'Educació $i$ de l'Esport, 32(1), 91-98.

Preacher, K.J., \& Hayes, A.F. (2008). Contemporary approaches to assessing mediation in communication research. The Sage sourcebook of advanced data analysis methods for communication research, 13-54. doi:10.4135/9781452272054.n2

Russell, D., Peplau, L. A., \& Ferguson, M. L. (1978). Developing a measure of loneliness. Journal of personality assessment, 42(3), 290-294. doi:10.1207/s15327752jpa4203_11

Shaikhamadi, S., Yousefi, F., Taymori, P., \& Roshani, D. (2018). The relationship between Internet addiction with depression and anxiety among Iranian adolescents. Chronic Diseases Journal, 5(2), 41-49. doi:10.22122/cdj.v5i2.234

Shaw, M., \& Black, D. W. (2008). Internet addiction. CNS drugs, 22(5), 353365.
Smith, H. M., \& Betz, N. E. (2000). Development and validation of a scale of perceived social self-efficacy. Journal of Career Assessment, 8, 283-301. doi:10.1177/106907270000800306

Şişman, M., \& Turan, S. (2004). A Study of Correlation between Job Satisfaction and Social-Emotional Loneness of Educational Administrators in Turkish Public Schools. Osmangazi University Journal of Social Sciences, 5(1): 117-128.

Tabachnick, B.G., \& Fidell, L.S. (2013). Using multivariate statistics. Boston: Pearson.

Turkish Statistical Institute (2018). [Address based population registration system]. Retrieved https://biruni.tuik.gov.tr/medas/?kn=95\&locale $=$ tr.

Ümmet, D., \& Ekşi, F. (2016). Internet addiction in young adults in Turkey: loneliness and virtual- environment loneliness. Addicta: The Turkish Journal On Addictions, 3(1), 29-53. doi:10.15805/addicta.2016.3.0008

Vadher, S. B., Panchal, B. N., Vala, A. U., Ratnani, I. J., Vasava, K. J., Desai, R. S., \& Shah, A. H. (2019). Predictors of problematic Internet use in school going adolescents of Bhavnagar, India. International Journal of Social Psychiatry, 65(2), 151-157. doi:10.1177/0020764019827985

Weiss, R.S. (1973). Loneliness: The experience of emotional and social isolation. Cambridge, MA: MIT Press.

Whang, L.S-M., Lee, S., \& Chang, G. (2003). Internet over-users' psychological profiles: A behavior sampling analysis on internet addiction. $C y$ berPsychology \& Behavior, 6(2), 143-150. doi:10.1089/109493103321640338

Worthington, R. L., \& Whittaker, T. A. (2006). Scale development research: a content analysis and recommendations for best practices. Counseling Psychology, 34, 806-838. doi:10.1177/0011000006288127

Wright, S. L., \& Perrone, K. M. (2010). An examination of the role of attachment and efficacy in life satisfaction. Counseling Psychologist, 38, 796823. doi: $10.1177 / 0011000009359204$

Wright, S. L., Wright, D. A., \& Jenkins-Guarnieri, M. A. (2013). Development of the social efficacy and social outcome expectations scale. Measurement and Evaluation in Counseling and Development, 46(3), 218-231. doi:10.1177/0748175613484042

Young K. S. (1998). Caught in the Net: How to Recognize the Signs of Internet Addiction and a Winning Strategy for Recovery. New York: John Wiley \& Sons.

Young, K. S. (2004). Internet addiction: A new clinical phenomenon and its consequences. American behavioral scientist, 48(4), 402-415. doi:10.1177/0002764204270278 